Mongolian Geoscientist

Review paper

\title{
Uranium deposits of Mongolia, their exploration and mine development
}

\author{
Dorjyunden Altankhuyag $^{1 *}$, Baldorj Baatartsogt ${ }^{2}$, Batbold Munkhtur ${ }^{3}$
}

\author{
${ }^{1}$ Department of Strategic Policy and Planning, Ministry of Mining and Heavy Industry, Mongolia, Ulaanbaatar 15160, Mongolia \\ ${ }^{2}$ Administration Department, Nuclear Energy Commission, Mongolia, Ulaanbaatar 17032, Mongolia \\ ${ }^{3}$ Department of Geology and Mining Policy Implementation and Coordination, Ministry of Mining and Heavy Industry, Mongolia, Ulaanbaatar \\ 15160, Mongolia \\ *Corresponding author.Email: aataadorj@gmail.com
}

\section{ARTICLE INFO}

Article history:

Received 9 May 2019

Accepted 26 September 2019

\begin{abstract}
Most of the known uranium deposits in Mongolia are related to volcano-tectonic structures of the Late Mesozoic and permeable sandstone aquifers of terrigenous sedimentary rocks in Late Mesozoic-Cenozoic basins. A young uranium deposit has been recently discovered at the surface in Quaternary alluvial sediments. Uranium deposits are classified here according to the International Atomic Energy Agency (IAEA) classification scheme. Beside of supergene and hydrothermal uranium discoveries, uranium mineralization can also be found in the Lower Cretaceous lignite seams, in Mesozoic alkaline intrusive rock related REE, Th, U enriched mineral systems and in metasomatic rocks, as well as in migmatites and pegmatites localized in Precambrian metamorphic rocks. Currently, no uranium can be produced in Mongolian facilities except pilot testing being done first. A pilot test was carried out at the Khairhan and Kharaat deposits in Mongolia and these experiments have demonstrated the ore to be amenable to acid leach (sulphuric acid) with the addition of an oxidizing agent. These tests confirmed that hydraulic control can be maintained and that the uranium solubilization and mobilization can be controlled. The results of the test were encouraging, with the well production rate, uranium concentration in produced solutions, chemical usage, and estimated uranium recovery all within ranges expected for normal commercial operations. There are a number of Mongolian uranium deposits are in the stage of mine development. The Government of Mongolia has approved the agreement of mine development of the Zuuvch ovoo and Dulaan uul deposits. Pilot testing on these deposits is underway and uranium will be extracted by in-situ leaching soon.
\end{abstract}

Keywords: Uranium metallogeny, classification, activity

\section{INTRODUCTION}

The Parliament of Mongolia endorsed the State policy on Use and Exploitation of Radioactive Minerals and Peaceful Uses of Nuclear Energy in 2009 and subsequently adopted Nuclear Energy Law in the same year.
The Nuclear Energy Law provides the government the right to take ownership without payment of not less than $51 \%$ of the shares of a project or joint venture if the uranium mineralization was discovered by State funded exploration, and not less than $34 \%$ if State

(C) The Author(s). 2019 Open access This article is distributed under the terms of the Creative Commons Attribution 4.0 International License (https://creativecommons.org/licenses/by/4.0/), which permits unrestricted use, distribution, and reproduction in any medium, provided you give appropriate credit to the original author(s) and source, provide a link to the Creative Commons license, and indicate if changes were made. 
funding was not used to find the mineralization. Licenses to conduct uranium exploration and production of any radioactive minerals must be obtained under this law.

The implementation of the state policy is not going as planned due to challenges related to public awareness and global energy policy trends in countries utilizing nuclear power. There are about 60 types of minerals in 2500 deposit areas found in Mongolia. The government of Mongolia is pushing deep into the development of infrastructure for the legal and regulatory frameworks of uranium exploration and exploitation to increase the state income based on the proven uranium reserves and its prospectus.

As cited in the Nuclear Energy Law of Mongolia, the Nuclear Energy Commission (NEC) is the head body in the nuclear energy field. The NEC is responsible for coordination and formulation of all activities embedded in the State policy, including development of science and technology, human resources development, exploitation of radioactive minerals and nuclear energy applications, radiation protection and nuclear safety, and promotion of the nuclear energy field within the territory of Mongolia, as well as implementation of international treaties and conventions on nuclear issues. The NEC issues licenses on nuclear material issues and nuclear facilities. It also adopts and endorses general nuclear and radiation safety regulations and rules on exploitation of radioactive minerals, radiation applications and nuclear energy, stipulated in Nuclear Energy Law (Chadraabal and Manlaijav, 2017).

The Mineral Resources and Petroleum Authority (MRPAM) under Ministry of Mining and Heavy Industry is responsible for exploration and mining licensing of radioactive minerals, whereas, the General Agency for Specialized Inspection bears the responsibility to provide for the government administrative inspection services in the country.

The NEC is playing a leading role in the development of a nuclear legal framework through drafting, formulating and renewing regulation and guidance based on the existing legislations and also studying best practices of developed countries, as well as cooperation with international organizations such as the IAEA and European Commission.

Mongolia is focusing on the development of its projects that will lead the country to the global uranium market in near future. To achieve this goal, the government is seeking to resolve challenges such as the public perception on nuclear energy, human resources development and infrastructure.

The government of Mongolia established MonAtom LLC in 2009 as the national operator of Mongolia for all uranium mining activities, including export and trade of uranium production. This company will be a partner to every uranium project and will hold the state shares stipulated in Nuclear Energy Law.

\section{GEOLOGICAL CLASSIFICATION OF URANIUM DEPOSITS}

Uranium deposits in Mongolia are based on the IAEA classification scheme (Bruneton and Cuney, 2016) and are described in order from deep primary (endogenic) magmatic deposits to (exogenic) sedimentary and surficial deposits following the geological cycle (Cuney, 2010). Subtypes are classified according to definition by Dahlkamp (Duhlkamp, 2009). Volcanicrelated, sandstone and exogenic type of uranium deposits are found, in addition to, graniterelated, metasomatite, lignite-coal and phosphate types of uranium mineralization (Jamsrandorj et al., 2016).

According to the investigation of confirmed sandstone-type uranium deposits (OECD(NEA)/ IAEA, 2005) and oil-gas, coal exploration and excavation, $82 \%$ of the total sandstone-type uranium deposits coexist with confirmed oil-gas fields and coal fields in the same basins (Liu et al., 2007). Energy resources, such as coal, oil and uranium are supplied from large sedimentary basins in Mongolia. In recent years, sandstone uranium deposits closely associated with hydrocarbon-bearing basins have been identified in the Zuunbayan basin, and similar basins are found at Matad, eastern Mongolia and Ail, southern Mongolia. Energy basins and subbasins distributed on the territory of Mongolia are shown in Fig. 1. 


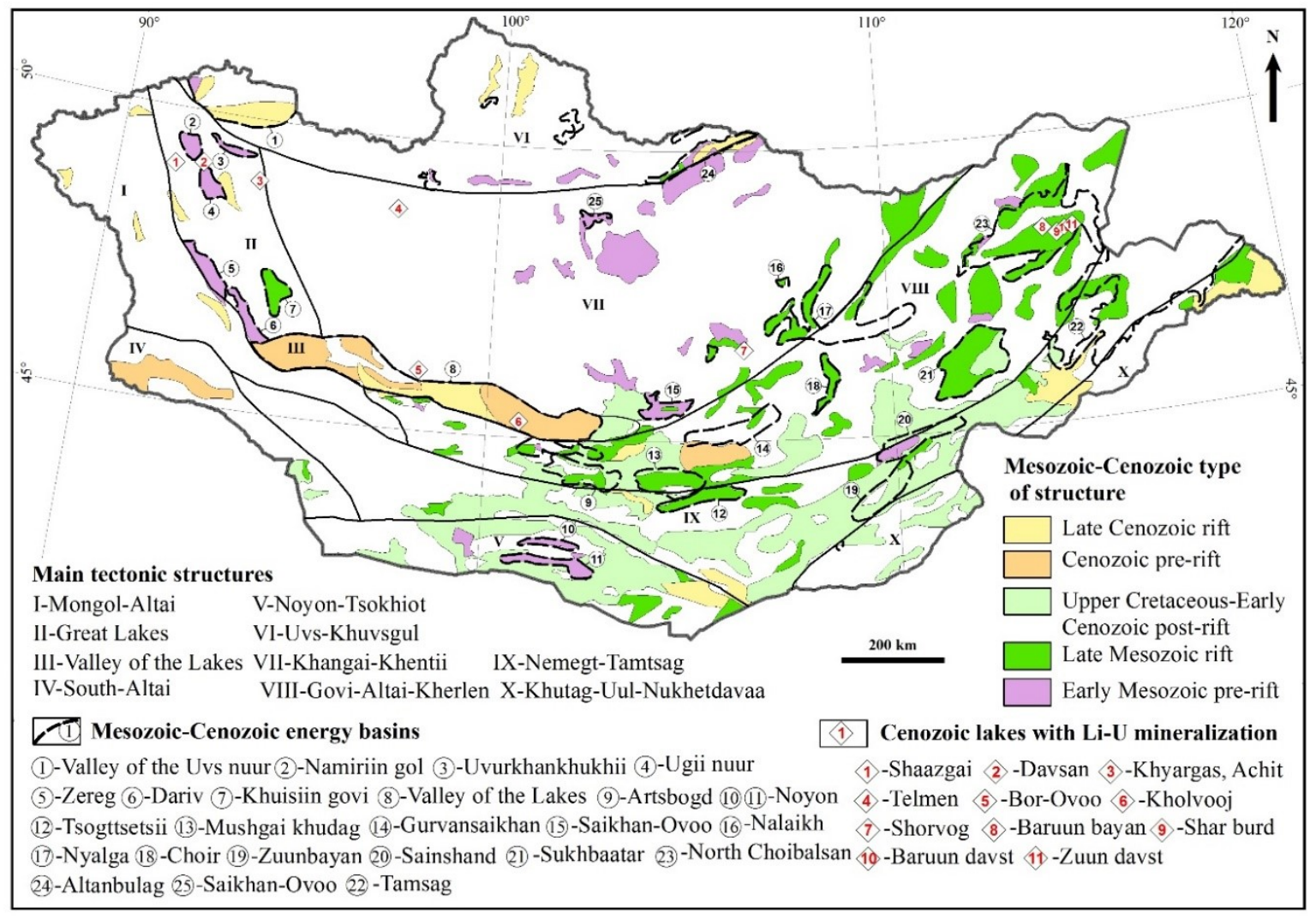

Fig. 1. Distribution of energy basins and main Mesozoic-Cenozoic tectonic structures (After Badamgarav et al., 2011).

\section{Volcanic-Related Deposits}

This type of uranium deposits is commonly located within volcanic calderas filled with bimodal volcanic and volcanoclastic sediments (Mironov, 2006). These deposits are characterized by fluorite-molybdenitepitchblende (+apatite) mineralization. The coincidence of the slab boundary projections and area of their influence with the spatial position of large F-Mo-U ore clusters separated from each other by hundreds of kilometres. Dornod, Gurvanbulag, Mardain gol, Khavar and Nemer deposits and numerous occurrences Northeastern and Central Mongolia are volcanic -related type.

\section{Dornod}

This deposit is hosted in volcanic rocks, composed of amygdaloidal and brecciated basalts and andesites. Uranium mineralization occurs as pitchblende-coffinite assemblages associated with carbonaceous matter in areas of structural preparation (Jamsrandorj et al., 2015).
Coffinite and pitchblende in association with galena, molybdenite and pyrite precipitated at the uranium ore mineralization sub-stage, and the quartz-carbonate-kaolinite stockwork with marcasite characterize the post- mineralization stage. Uranium bearing keritic carbonaceous material was detected in the ore in addition to coffinite and pitchblende. Molybdenum is of economic importance in the stockwork zone together with uranium. Uranophane, autunite, uranotil, and uranospinite occur in the zone of oxidation.

\section{Gurvanbulag}

The main uranium minerals at Gurvanbulag deposit are coffinite, uranophane and pitchblende. Alteration accompanying the uranium mineralization was generally weak, being limited to silicification, and hematite and chlorite. Some fluorite may have been introduced at this stage. Post-uranium mineralization alteration minerals are quartz, fluorite, hydromicas, chlorite, kaolinite (dickite), 
montmorillonite, zeolites (analcime), and carbonates.

Molybdenite and other sulphides occur in small quantities include galena, sphalerite and chalcopyrite.

\section{Sandstone Deposits}

The sandstone uranium deposits occur in medium to coarse grained terrigenous sedimentary rocks in the Late MesozoicCenozoic basins in Mongolia. This type of uranium mineralization is closely related to uranium-enriched source rocks and permeable sandstone aquifers. The Kharaat, Khairhan, Dulaan uul, Zuuvch ovoo, Gurvansaikhan, Ulziit, Engerar deposits and other occurrences are situated in the Choir, Khairhan, Zuunbayan, Unegt basins of the southeast Gobi. Typically, sandstone hosted uranium occurrences are precipitated by reduction processes. The highest grade of mineralization is hosted in the medium to coarse grained sandy, lacustrine sediments. Sandstone hosted uranium deposits of Mongolia can be classified roll-front and basal channel or paleovalley sub-type (Budunov, 2006; Hocquet, 2016).

\section{Zuuvch ovoo and Dulaan uul}

The Dulaan uul is a sedimentary uranium deposit characterized by non-permeating thin argillaceous layers dominated by sand and uneven thickness and are divided into mineralized layers. An oxidized zone is distributed mainly in the south of the valley, whereas, a redox zone is mainly in the north, but also in the center of the Unegt sub-basin.

The uranium in the Zuuvch ovoo deposit in the Zuunbayan valley mainly occurs in layers of the
Sainshand Formation upper member. The thickness of the sandy layer with the main uranium ore ranges between 35 and $40 \mathrm{~m}$ (Fig. 2 ), and its composition is uniform and has medium and large sand granules and small organic scatterings. Oxidation-redox boundaries in sedimentary bed stratification are characterized by grey-yellow sand for the oxidation zone and grey feldspar grains and coal clasts in the reduced zone. Pyrite, kaolinite and rare hematite are present at the edge of the redox front. The reduced sandstone has higher radioactivity values. The structure and hydrogeological conditions of this valley played an important role for uranium accumulation. Electron microscopy analyses on the uranium bearing samples indicated that uranium occurs in lignite as micro grains, and rarely as uraniumiron micro grains in the quartz grains. As result of above analysis, uranium is relatively mobile and amenable to acid leaching. Cogegobi has been holding a majority of exploration licenses among exploration companies and played a main role in the discovery of Zuuvch ovoo (67 706.77 tons of U), Dulaan uul (7054.71 tons of $\mathrm{U})$ and Umnut (4746.14 tons of $U$ ) deposits in Dornogobi province.

\section{Kharaat}

The Kharaat uranium deposit is located in a late Mesozoic extensional basin, which in central east Mongolia. These basins, are likely fault bounded grabens and half grabens, and were filled by terrigenous sediments during the Jurassic and Cretaceous periods) Budunov and Jamsrandorj, 2012). The variegated section is comprised of conglomerate, sandstone, and siltstone, and occurs mainly on the margins of

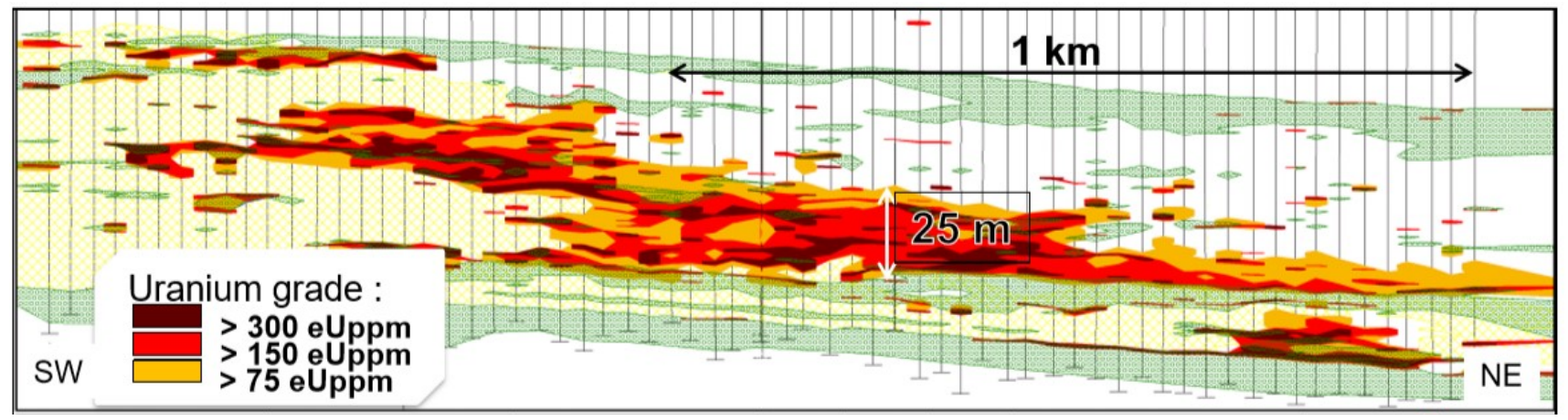

Fig. 2. Schematic cross section and distribution of uranium of Zuuvch ovoo deposit (After Hocquet, 
the depression. The facies is comprised of lacustrine sediments, typically clays and argillaceous sandstone, with interbeds of brown coal and disseminated iron sulphides. Mineralization is present in significant concentrations both above and below the water table. Typically, mineralization below the water table occurs in grey-coloured rocks or at the interface of the red oxidized rocks.

Mineralization below the water table occurs primarily as uraninite with smaller amounts of coffinite. The uranium minerals occur as films and diffuse haloes on and between individual rock fragments and sand grains. In the oxidizing environment above the water table, secondary uranium minerals are present and include autunite, bergenite, phosphuranylite, schroeckingerite, torbenite, and minor amounts of other uranophosphates.

In the Choir basin, greater than $70 \%$ of the known mineralization with potentially economic grade occurs above the natural water table. Full saturation of the ore-bearing section is the normal condition for in situ recovery; however, the In Situ Recovery (ISR) test at Kharaat included leaching from both saturated and unsaturated horizons.

\section{Khairhan}

The Khairhan deposit is located in the northwest part of the Khairhan basin. The Khairhan basin is filled by coal-bearing gray colored Cretaceous Zuunbayan Formation and covered by Sainshand Formation around south edge. The host sedimentary rocks of the Khairhan deposit consist of unconformable clastic and lacustrine sandstones and shales. The ore is aluminosilicate and carbonate-free. Uranium mineralization is mainly represented by pitchblende; coffinite is of secondary importance. Autunite and uranophane occur in the oxidized rocks. Molybdenum is the main associated element; the Mo grade in the ore reaches $0.05 \%$. The hydrogeological conditions at the deposit are complex but generally favorable for uranium recovery by underground leaching. The ore mineralization is localized below the groundwater table, being largely hosted in permeable rocks. The uranium concentration is controlled by reduction, and the oxidized zone serves as a supplier of uranium to the redox front.

\section{CURRENT ACTIVITIES Exploration and Reserves}

For uranium deposits, the major preparatory work for the recovery is underway due to the completion of deposit development agreements between the government and potential stakeholders. Mongolia is focusing on the potential projects that will lead the country to the world uranium market in the near future. Through the experiences over the past few years, the uranium exploration entities are deemed as essential for the social licensing in potential mining areas in line with the State Policy.

The history of uranium exploration in Mongolia could be divided into three phases. The first phase started in the middle of the 1940s, whereas the second phase covers a period of 1970 to 1990 where the specialized geological surveys were conducted with a result of 1,600 of radioactive anomalies and hundreds of occurrences identified by the joint expedition with the Ministry of Geology of the Soviet Union under a bilateral agreement between the People's Republic of Mongolia and the Soviet Union. The third phase started in 1990s with the private stakeholder's engagements including local and foreign entities. Due to the prevalence of findings, features of mineralization and significance to manufacturing, Mongolia's eastern, south-eastern and central regions are relatively well-studied. It is estimated that there are about 1.47 and $1.0 \mathrm{Mt}$ of $\mathrm{U}$ resources in total by Mironov in 1993, and Jamsrandorj et al., in 2016, respectively. According to the statistics of Mineral Resources and Petroleum Authority of Mongolia, uranium reserves are assessed at 166,657 tons of $U$ in total by 2019 .

The depletion of costs uranium causes the exploration strategy changes globally to the low cost uranium, especially sandstone type deposits. Therefore, uranium exploration was focused and targeted on Mesozoic and Cenozoic basins in south-east Mongolia.

The "Uranium" state-owned manufacturing enterprise, in cooperation with the IAEA, conducted a project entitled "The state of 
uranium in Mongolia and its assessment" in two phases between 1993 and 2001, completing the topical research work on "Mineralization of sedimentary and metasomatic uranium." Within this research project, a related research work on the radioactivity of coal deposits and construction-related mines in Ulaanbaatar, Baganuur, Shivee-Ovoo was conducted. Since then, geological studies, prospecting and exploration of radioactive minerals have not been funded by the state budget. Recent years (2016-2018), the government has conducted airborne and ground geophysical survey covering southwest Mongolia. Based on the result of gamma spectrometric survey, the Baruunkhurai, Gobi-Tengeruul, Khustiinnuruu, Songinot uranium potential zones were described and most of these anomalies could be related to alkaline granites with REE mineralization.

The Dornod open pit mine and underground orebody was mined between 1988 and 1995 . The ore was railed $480 \mathrm{~km}$ to Krasnokamensk in Siberia for treatment by Priargunsk enterprise. Only about 535 tons of $U$ was produced, all from open pit mining. Gurvanbulag, about 30 $\mathrm{km}$ west of Dornod, had extensive underground development down to 560 metres in the Soviet era, and was readied for production. The metallurgical testwork at the Dornod deposit has been done and reported by Russian side before 1990s. These documents provide information on the various process options investigated and unfortunately, conventional Pachuca leaching was not extensively evaluated. In the Russian work, only limited results were found to indicate the recovery that might be expected from the deposit using acid leaching under atmospheric conditions. The processing plant that has been designed for the Gurvanbulag operation is based on a Resin Extraction Process. The first stage of processing is the sorting stage. This is followed by grinding, leaching, the resin extraction process and elution, product precipitation, and finally calcination and packaging. The processing recovery was considered at around $95 \%$.

\section{Preparatory Work for the Uranium Exploitation}

There are currently eight deposits on which Feasibility Studies have been completed and approved by Mongolian Professional Committee of Resources. These studies reflect that "Areva Mines" LLC will begin exploitation of the Dulaan uul and Zuuvch ovoo deposits beginning in 2022. "Emeelt Mines" LLC will begin exploitation of the Gurvanbulag deposit beginning in 2018 according to their Feasibility Studies. In Mongolia, Areva Mongol LLC, subsidiary of Areva Group in Mongolia, and Uranium Industry LLC of the Czech Republic have been leading entities in the uranium mining sector up to now.

The Orano Group, formerly known as Areva Group, has been active in Mongolia since 1997 and created Cogegobi LLC with a local company named Gobigeo LLC $(30 \%$ shares of the company) to conduct geological and exploration work with a view to identifying prospective areas of uranium concentration. Since 2009, Cogegobi has been fully owned by Areva Mongol.

One of the potential projects is Zuuvch ovoo, Dulaan uul uranium project in Dornogobi province in east-south region of Mongolia. The deposit will be mined by in-situ leaching method using a sulphuric acid. There was an ISR semiproduction test on the Umnud site in Dulaan uul in 2010-2011. 2.9 tons of uranium was fixed in resin from 2 test cells. The total reserve of the ore was 3.4 tons. There was a column leaching test and the test to determine conditions on 32.9 $\mathrm{kg}$ of samples from five wells in the Zuuvch ovoo deposit in 2011-2012. There were a column leaching test and a titration test for the purpose of confirming the results of the previous test in 2013.

The Nuclear Energy Law requires a mining licensee to sign a Deposit development agreement with the MRPAM, so Areva Mongol signed this agreement with the MRPAM in July 2016. The company is going to conduct a pilot test in Zuuvch ovoo and obtain statistical information in Feasibility Studies, covering the Zuuvch ovoo and Dulaan uul deposits, which was approved by Mongolian Professional Committee of Resources in 2015. Areva Mongol 
previously conducted a pilot test in the Dulaan uul in 2011. Another major agreement cited in the Nuclear Energy Law is an investment agreement between an undisclosed licensee and the Government. Uranium production is expected to start in 2022.

In 1994, a small ISR test was run at Kharaat to determine the amenability of the deposits to ISR technology. The success of this work led to more significant testing in 1996. This involved the acquisition, assembly, and operation of an ISR Pilot Plant at Kharaat. The plant was a fully integrated facility, capable of producing final product, although drying and packaging equipment were not included. The plant handled a nominal flow rate of $20 \mathrm{~m}^{3} / \mathrm{h}$, although under optimal conditions, it could be operated at a higher rate. The plant consisted of an ion exchange circuit, a resin desorption and regeneration circuit, a uranium precipitation circuit, and all of the necessary ancillary and support facilities.

The testing in 1996 included tests of the recovery of mineralization both above and below the water table, the latter being the normal operating regime for an ISR project. Sulphuric acid was the primary leaching agent used in both tests. These tests confirmed that hydraulic control can be maintained and that the uranium solubilization and mobilization can be controlled. Both tests encountered operating circumstances that pointed out the necessity to conduct further commercial scale testing at Kharaat. The test above the water table is believed to be the only work of this kind that has been conducted in the world. While in-place leaching of unsaturated mineralization has been shown to be possible, further work is necessary to confirm the economic viability of this method.

An initial ISR test was completed in 1998 to determine the appropriate leach chemistry and to verify it under actual field conditions. The test consisted of a single production well surrounded by four injection wells and associated monitoring wells. The ion exchange and resin desorption and regeneration equipment from the Kharaat ISR Pilot Plant was assembled at Khairhan. The test was operated for about fourteen weeks and was terminated with the onset of freezing weather.

The 1998 Khairhan test confirmed the leachability of the mineralization at Khairhan. Although a single, small test may not be completely definitive, the results of the Khairhan test were encouraging, with the well production rate, uranium concentration in produced solutions, chemical usage, and estimated uranium recovery all within ranges expected for normal commercial operations.

Deposits containing geological reserves of 23,019 tons of $U$ occur in Dundgobi and Sukhbaatar provinces covering an area of 28,490 hectares. Deposits were discovered in 20092013 and Feasibility Studies for Kharaat and Khairkhan were done in 2011 and Gurvansaikhan and Ulziit in 2014, respectively. Environmental Impact Assessment was approved by the Ministry of Environment in 2011. As approved in Feasibility Studies for those four deposits, the extractions are conducted by In Situ Leaching technology.

The licensee of these Kharaat, Khairhan, Gurvansaikhan and Ulziit deposits is Gurvansaikhan LLC, a subsidiary of Uranium Industry LLC of the Czech Republic. Uranium Industry LLC purchased Gurvansaikhan LLC from Denison Mines Corporation in 2015. Gurvansaikhan LLC signed a Deposit development agreement for those four deposits with MRPAM in September 2016.

\section{Infrastructure}

There are some issues such as required investment volume, qualified human resources and local infrastructure, as well as the legal environment for conducting mining operations of radioactive minerals. During this period where ISL technology is being introduced, there is a need to study the advantages and disadvantages of technologies, safe operations, features, modes and standards of technology and knowledge base. This will enable the technology to be introduced as well as provide a public with key information and awareness related to uranium extraction technologies.

Furthermore, infrastructure questions must be considered alongside questions related to energy, transportation, water management and rural development. The work is being done to 
reflect these issues related to uranium extraction in order to be comprehensively reflected in Deposit Development Agreement, Investment Agreement and other related legal documents of the company.

\section{CONCLUSIONS}

Mongolia is carrying out preparatory studies in order to commercialize radioactive minerals. As part of these studies, Mongolia is working to introduce legislations concerning extraction of radioactive minerals to improve legal environment and being consistent the best international practice.

Thus, Mongolia is actively working to increase uranium reserves, attract investment and begin exploiting deposits with proven reserves and also build trust between stakeholders. Through the experiences over the past few years, the uranium exploration entities are deemed as essential for the social licensing in areas in line with the State policy.

In recent years, low cost uranium, especially sandstone type, deposits have been discovered in Mongolia, which is highly likely to attract more international uranium exploration and production companies. As a result, uranium production is expected to be commenced in the near future.

\section{REFERENCES}

Badamgarav, J., Badamgarav, D., Orolmaa, D., Tomorkhuu, D., Narantsetseg, Ts., Dembereldagva, Ts., Idermonkh, T. 2011. Map of the Mesozoic-Cenozoic tectonic structures of Mongolia. Scale 1:1000000.

Bruneton, P., Cuney, M. 2016. Geology of Uranium Deposits. In: Hore-Lacy I (ed) Uranium for Nuclear Power, Resources, Mining and Transformation to Fuel. Woodhead, London, 11-53. https:// doi.org/10.1016/B978-0-08-100307-7.00002-8
Budunov, A.A. 2006. Summary Report of Results of Prospecting Work in the Gobi Region of Mongolia for 1994-1996. Ulaanbaatar.

Budunov, A.A., Jamsrandorj, G. 2012. Kharaat uranium deposit. Prospector 47, 76-81 (in Mongolian).

Chadraabal, M., Manlaijav, G. 2017. Current Status of uranium activities in Mongolia. The AusIMM International Uranium Conference.

Cuney, M. 2010. Evolution of uranium fractionation processes through time: driving the secular variation of uranium deposit types. Economic Geology, 105, 449-465. https:// doi.org/10.2113/gsecongeo.105.3.553

Dahlkamp, F.J. 2009. Uranium deposits of the world, Asia. vol 4. Springer, Berlin. https:// doi.org/10.1007/978-3-540-78558-3

Hocquet, S. 2016. Zoovch Ovoo and Dulaan Uul uranium deposits. Cogegobi LLC, IAEAUNECE Workshop, 16/08/2016, Ulaanbaatar.

Jamsrandorj, G., Baatartsogt, B., Altankhuyag, D. 2016. Recent Discoveries and Resources of Uranium in Mongolia. Journal of East China University of Technology 39, 25-31.

Jamsrandorj, G., Dejidmaa, G., Ukhnaa, G. 2015. Uranium: The geology, world overview of mineral resources and mining. Ulaanbaatar (in Mongolian).

Mineral Resources and Petroleum Authority of Mongolia (MRPAM), 2017. The Annual report 2016.

Mironov, Y.B. 2006. Uranium of Mongolia. Center for Russian and Central EurAsian Mineral Studies (CERCAMS), London 230 p. (In Russian).

OECD(NEA)/IAEA. 2004. Uranium 2003: Resources, Production and Demand, OECD, Paris, 186 p. 